\title{
Is there a difference between the right and left kidney? A macroscopic approach in Brazilian Shorthair Cat
}

\author{
[Existe diferença entre o rim direito e o rim esquerdo? Uma abordagem macroscópica em gato \\ pelo curto brasileiro] \\ A.V. Stocco ${ }^{1}$, C.A. Santos Sousa ${ }^{1}$, M.S, Gomes ${ }^{1}$, P. Souza Júnior ${ }^{2}$, M. Abidu Figueiredo ${ }^{1 *}$ \\ ${ }^{1}$ Universidade Federal Rural do Rio de Janeiro - UFRRJ - Seropédica, RJ \\ ${ }^{2}$ Universidade Federal do Pampa - Uruguaiana, RS
}

\begin{abstract}
The aim of this study was to characterize the renal morphology and anatomical variations of the renal pedicle in domestic shorthaired cats. Dissections were performed in 40 adult cats, obtained from the necropsy unit without macroscopic renal pathology. Kidney dimensions (length, width, and thickness) and the length and origin of the renal arteries and main branches were measured. The length, width and thickness of the right kidney $(\mathrm{cm})$ were $3.83 \pm 0.46,2.42 \pm 0.22$, and $2.22 \pm 0.33$ in males, and $3.61 \pm 0.53$, $2.28 \pm 0.38$, and $2.13 \pm 0.40$ in females, respectively. In the left kidney, these measures were $3.82 \pm 0.32$, $2.48 \pm 0.31$, and $2.37 \pm 0.32$ in males, and $3.48 \pm 0.47,2.39 \pm 0.26$, and $2.15 \pm 0.34$ in females, respectively. The left kidneys of males were significantly bigger than those of females. There was a positive linear correlation between the rostrum-sacral length and ellipsoid volume of the left kidney only in males. Most of the kidneys were situated ventrally between the third to fifth lumbar vertebras. The right renal artery was situated ventrally to third lumbar vertebra and the left artery to the fourth. The results of the present study contribute to the field of comparative and applied anatomy.
\end{abstract}

Keywords: domestic feline, renal measures, vascularization

\section{RESUMO}

O objetivo deste estudo foi caracterizar a morfologia renal e as variações anatômicas do pedículo renal em gatos de pelo curto brasileiro. As dissecções foram realizadas em 40 gatos adultos, obtidos de necropsias sem evidência de patologia renal macroscópica. Medidas renais (comprimento, largura e espessura), comprimento e origem das artérias renais e ramos principais foram obtidos. $O$ comprimento, a largura e a espessura do rim direito $(\mathrm{cm})$ foram 3,83 $\pm 0,46,2,42 \pm 0,22$ e 2,22 $\pm 0,33$ em machos e 3,61 $\pm 0,53,2,28 \pm 0,38$ e 2,13 $\pm 0,40$ em fêmeas, respectivamente. No rim esquerdo, essas medidas foram 3,82 \pm 0,32, 2,48 \pm 0,31 e 2,37 \pm 0,32 em machos e 3,48 $\pm 0,47,2,39 \pm 0,26$ e 2,15 $\pm 0,34$ em fêmeas, respectivamente. O rim esquerdo dos machos foi maior do que o das fêmeas. Houve correlação linear positiva entre o comprimento rostrossacral e o volume elipsoide do rim esquerdo apenas em machos. A maioria dos rins estão situados ventralmente entre a terceira e quinta vértebras lombares. A artéria renal direita está situada ventralmente na terceira vértebra lombar, e a artéria renal esquerda na quarta. Os resultados do presente estudo contribuem para a anatomia comparada e aplicada.

Palavras-chaves: felinos domésticos, medidas renais, vascularização

\section{INTRODUCTION}

The renal dimensions in humans and animals are very useful diagnostic parameters both in urological as well as nephrologic practice.
Many animals have been used as experimental models for urologic procedures. Pigs are more often used because their kidney most closely resembles the structural features of the human kidney (Sampaio et al., 1998). On the other hand,

Recebido em 3 de abril de 2015

Aceito em 4 de abril de 2016

*Autor para correspondência (corresponding author)

E-mail: marceloabidu@gmail.com 
cats have been used in bilateral renal ischemia as a model of acute kidney injury (Schmiedt et al., 2012).

Background knowledge of normal renal dimensions (RD) may help in the diagnosis of kidney diseases. Renal dimensional variations occur in nephropathies due to hypertrophic process and/or atrophy (Elkin, 1980). Thus, it is imperative to establish the pattern of normal renal dimensions. It has been postulated from necropsy studies that variations in RD and renal weight are related to gender, with weight being higher in males. It is also known that the left kidney is larger than the right one, regardless of gender (Möell, 1956).

The aim of this study was to obtain a better understanding of the renal morphometry and anatomical variations of the renal pedicle in cats.

\section{MATERIAL AND METHODS}

The research ethics committee of Rio de Janeiro Federal Rural University approved this study (23083.005334/2009-49). Fixation was done by caudally injecting a $10 \%$ formaldehyde solution through the catheter (variable volume depending on the cadaver's weight). Immediately after fixation of the cadavers, Petrolátex S65 solution (Duque de Caxias Refinery, Petrobrás, Duque de Caxias, RJ - Brazil) mixed with Suvinil pigment was injected to fill the entire arterial system. Then each cadaver was immersed in a lowdensity polyethylene cardboard box with 500 liters capacity containing a 10\% formaldehyde solution to finalize the fixation and latex polymerization process.

Anatomical dissections were performed in 40 adult shorthaired cats without macroscopic renal pathology: 20 males and 20 females with a rostrum-sacral length of $48.25 \pm 0.56 \mathrm{~cm}$ and $45.19 \pm 0.70 \mathrm{~cm}$, respectively. The animals were obtained from the university's necropsy unit. The abdomen was opened by an incision on the white line followed by another caudal on the last rib to expose the abdominal organs. The abdominal aorta artery was dissected immediately caudal to the diaphragm until the emergence of the renal arteries. The abdominal aorta artery was cannulated with a plastic stem. The kidneys were "in situ" dissected to characterize the skeletopy. Kidney measurements were made with a digital caliper: length (distance between the cranial and caudal poles), width (distance between the medial and lateral borders), and thickness (distance between the dorsal and ventral surfaces). The ellipsoid volume of the kidney was estimated (Sampaio, 1995). The length and origin of the renal arteries and main branches and length of the renal veins were also determined. The dissected materials were imaged using a Nikon Coolpix L820 model camera.

The mean and standard deviation of the kidney and renal vessel measurements were calculated and compared in both sexes by the unpaired $t$ test. To verify if the frequency distributions observed for the 40 animals were in accordance with the literature, the Chi-square $\left(\chi^{2}\right)$ test was performed to test the null hypothesis for skeletopy of the right and left kidneys. The relation between the renal measures and the rostrum-sacral length was calculated by the coefficient of correlation " $r$ " varying between -1 and +1 . A value of

$\mathrm{P}<0.05$ was considered statistically significant.

\section{RESULTS}

In all animals in which the renal arteries were dissected emerged as a single vessel laterally directly from the abdominal aorta (Fig. 1). The renal veins drain in caudal vena cava in all cats

The results of the kidney and vessel measurements are shown in Tab. 1, 2 and 3.

The renal artery skeletopy related to lumbar vertebra is represented in (Tab. 4). In males, there was a bifurcation in the right renal artery in one animal $(5 \%)$. The right renal artery also issued the following branches: to the adrenal gland in eight animals (40\%) and to the ureter in 15 animals $(75 \%)$. The left renal artery presented a bifurcation in five animals $(25 \%)$ and issued the following branches: to the adrenal gland in 13 animals $(65 \%)$ and to the ureter in 14 animals $(70 \%)$. 


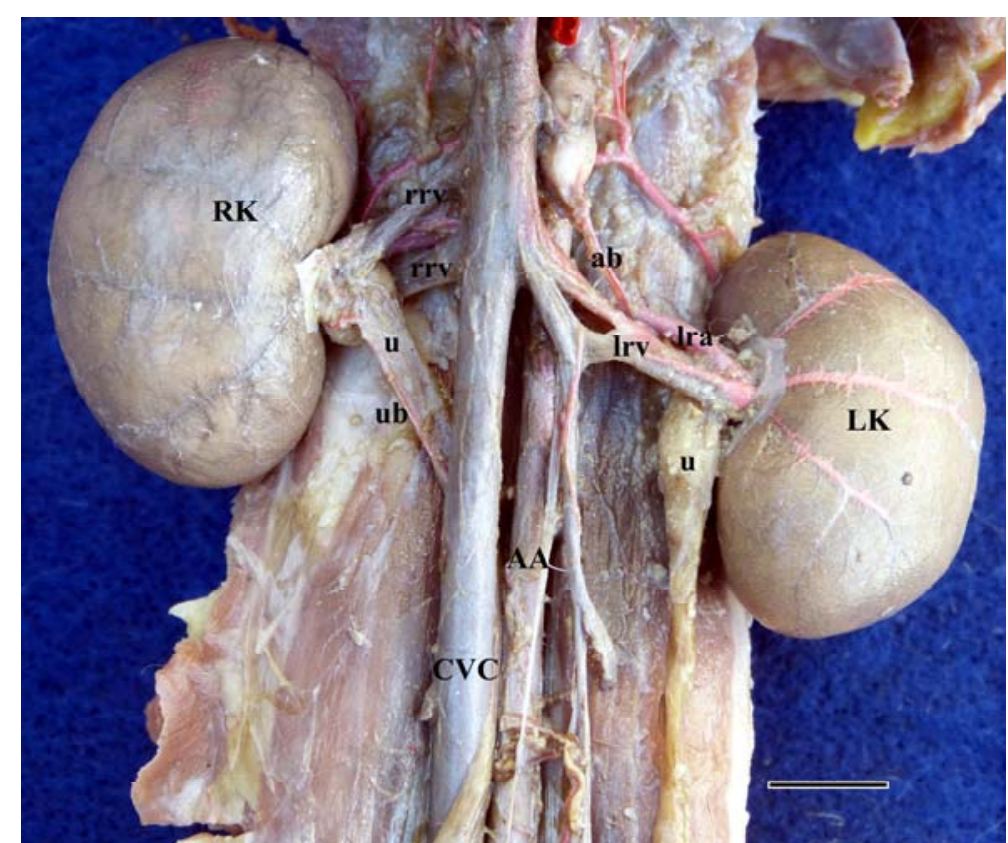

Figure 1. RK - right kidney; LK - left kidney; AA- abdominal aorta, CVC - caudal vena cava; rrv - right renal vein; lrv - left renal vein; lra-left renal artery u- ureter; ub- ureteral branch; ab- adrenal branch.

Table 1. Comparison of the kidney and vessel measurements $(\mathrm{cm})$ between genders in domestic shorthair cats $(n=20$, each sex $)$

\begin{tabular}{lccc} 
& \multicolumn{3}{c}{ Cats } \\
\cline { 2 - 4 } & Males & Females & p-value \\
\hline Length of the right kidney & $3.83 \pm 0.46$ & $3.61 \pm 0.53$ & 0.18 \\
Length of the left kidney & $3.82 \pm 0.32$ & $3.48 \pm 0.47$ & $0.01^{*}$ \\
Width of the right kidney & $2.42 \pm 0.22$ & $2.28 \pm 0.38$ & 0.16 \\
Width of the left kidney & $2.48 \pm 0.31$ & $2.39 \pm 0.26$ & 0.31 \\
Thickness of the right kidney & $2.22 \pm 0.33$ & $2.13 \pm 0.40$ & 0.42 \\
Thickness of the left kidney & $2.37 \pm 0.32$ & $2.15 \pm 0.34$ & $0.04^{*}$ \\
Ellipsoid Volume of the right kidney $\left(\mathrm{cm}^{3}\right)$ & $11.14 \pm 3.31$ & $9.72 \pm 4.13$ & 0.24 \\
Ellipsoid Volume of the left kidney $\left(\mathrm{cm}^{3}\right)$ & $12.05 \pm 3.48$ & $9.72 \pm 3.34$ & $0.04^{*}$ \\
Length of the right renal artery & $1.73 \pm 0.55$ & $1.67 \pm 0.61$ & 0.74 \\
Length of the left renal artery & $1.89 \pm 0.61$ & $1.44 \pm 0.60$ & $0.03^{*}$ \\
Length of the right renal vein & $1.86 \pm 0.42$ & $1.70 \pm 0.41$ & 0.22 \\
Length of the left renal vein & $2.29 \pm 0.69$ & $1.99 \pm 0.66$ & 0.16 \\
\hline$* P<0,05$ & & & \\
\end{tabular}

Table 2. Comparison of the kidney and vessel measurements $(\mathrm{cm})$ between antimers in male domestic shorthair cats $(n=20)$

\begin{tabular}{cccc} 
& \multicolumn{3}{c}{ Males } \\
\cline { 2 - 4 } & Right & Left & p-value \\
\hline Renal length & $3.83 \pm 0.46$ & $3.82 \pm 0.32$ & 0.96 \\
Renal width & $2.42 \pm 0.22$ & $2.48 \pm 0.31$ & 0.51 \\
Renal thickness & $2.22 \pm 0.33$ & $2.37 \pm 0.32$ & 0.18 \\
Ellipsoid Volume $\left(\mathrm{cm}^{3}\right)$ & $11.14 \pm 3.31$ & $12.05 \pm 3.48$ & 0.39 \\
Renal artery length & $1.73 \pm 0.55$ & $1.89 \pm 0.61$ & 0.40 \\
Renal vein length & $1.86 \pm 0.42$ & $2.29 \pm 0.69$ & $0.02 *$ \\
\hline
\end{tabular}




\section{Stocco et al.}

Table 3. Comparison of the kidney and vessel measurements $(\mathrm{cm})$ between antimers in female domestic shorthair cats $(n=20)$

\begin{tabular}{|c|c|c|c|}
\hline & \multicolumn{3}{|l|}{ Females } \\
\hline & Right & Left & $\mathrm{p}$-value \\
\hline Renal length & $3.61 \pm 0.53$ & $3.48 \pm 0.47$ & 0.41 \\
\hline Renal width & $2.28 \pm 0.38$ & $2.39 \pm 0.26$ & 0.31 \\
\hline Renal thickness & $2.13 \pm 0.40$ & $2.15 \pm 0.34$ & 0.84 \\
\hline Ellipsoid Volume $\left(\mathrm{cm}^{3}\right)^{*}$ & $9.72 \pm 4.13$ & $9.72 \pm 3.34$ & 0.99 \\
\hline Renal artery length & $1.67 \pm 0.61$ & $1.44 \pm 0.60$ & 0.26 \\
\hline Renal vein length & $1.70 \pm 0.41$ & $1.99 \pm 0.66$ & 0.11 \\
\hline
\end{tabular}

In females, the right renal artery issued the following branches: to the adrenal gland in eight animals $(40 \%)$ and to the ureter in 13 animals $(65 \%)$. The left renal artery showed a bifurcation in two animals $(10 \%)$ and also issued branches to the adrenal gland in 12 animals $(60 \%)$ and to the ureter in 15 animals (75\%).

Table 4. Absolute and percentage frequencies of renal artery skeletopy at the level of lumbar vertebras in male and female domestic shorthaired cats

\begin{tabular}{ccccc}
\multirow{2}{*}{ Renal artery skeletopy } & \multicolumn{2}{c}{ Male $(\mathrm{n}=20)$} & \multicolumn{2}{c}{ Female $(\mathrm{n}=20)$} \\
\cline { 2 - 5 } & Right & Left & Right & Left \\
\hline L2 & $3(15 \%)$ & - & $1(5 \%)$ & - \\
L3 & $12(60 \%)$ & $7(35 \%)$ & $11(55 \%)$ & $1(5 \%)$ \\
L4 & $5(25 \%)$ & $13(65 \%)$ & $8(40 \%)$ & $19(95 \%)$ \\
\hline
\end{tabular}

In males the right renal veins were double in two animals $(10 \%)$, triple in three $(15 \%)$ and single in $15(75 \%)$. The left renal veins were double in four animals (20\%) and single in $16(80 \%)$. In females the right renal veins were double in five animals $(25 \%)$ and single in $15(75 \%)$. The left renal veins were double in one animal $(5 \%)$ and single in $19(95 \%)$.

The renal skeletopy of left and right kidneys related to thoracic and lumbar vertebras in male and female cats is summarized in Tab. 5.

Table 5. Absolute and percentage frequencies of right and left kidney skeletopy in male and female domestic shorthaired cats

\begin{tabular}{ccccc}
\hline & \multicolumn{2}{c}{ Male $(\mathrm{n}=20)$} & \multicolumn{2}{c}{ Female $(\mathrm{n}=20)$} \\
\cline { 2 - 5 } Skeletopy & Right & Left & Right & Left \\
\hline T13-L1 & - & - & $1(5 \%)$ & - \\
L2-L4 & $6(30 \%)$ & - & $10(50 \%)$ & $1(5 \%)$ \\
L2-L5 & $2(10 \%)$ & - & $1(5 \%)$ & - \\
L3-L5 & $12(60 \%)$ & $18(90 \%)$ & $7(35 \%)$ & $18(90 \%)$ \\
L3-L6 & - & - & $1(5 \%)$ & - \\
L4-L6 & - & $2(10 \%)$ & - & $1(5 \%)$ \\
\hline
\end{tabular}

\section{DISCUSSION}

Morphometry is the scientific study of the dimensions of gross anatomical structures of organisms, with particular reference to their linear measurements and weights. These are often obtained by direct measurements of formalin-fixed specimens, especially of the brain. Results have varied and accuracies are still being discussed (Peters et al., 1998).

Renal length and volume measurements are clinically relevant, serving as surrogates for renal functional reserve, and are used frequently as the basis for making clinical decisions. Serial measurements can also provide information 
regarding disease progression or stability. Renal disease can increase or decrease kidney size, and may or may not be accompanied by changes to the normal organ structure.

Nine hundred and four normal intravenous pyelographs, 581 from men and 323 from women, were analyzed in a previous study (Fernandes et al., 2002). Data obtained by measurement of right and left kidneys agreed with data from other studies, showing that the left kidney is larger than the right (Sampaio and Mandarin-de-Lacerda, 1989).

A recent study associated the renal length to several anthropometric variables in a group of healthy Mexican adults and concluded that renal size and height were shorter in that population compared with figures published by Europeans (Oyela-Carrasco et al., 2009).

They also noted that the left renal length was significantly greater than right renal length and that both renal lengths were greater in men than women in that population.

An ultrasonography study of human renal dimensions in normal adult population of northeastern India, in both sexes and different ages (Gupta et al., 2013), found no significant differences in any of the renal dimensions between the right and left kidneys in either sex, although the dimensions of the left kidney were somewhat greater than the right. An important observation made was that there was a significant difference $(\mathrm{P}<0.01)$ in the width of both the kidneys when comparing them between the male and female population. Similarly, there was a significant difference $(\mathrm{P}=0.008)$ in the size of the left kidney between the two sexes.

In the present study there was no significant difference seen in any of the renal dimensions between the right and left kidneys, however male cats have larger kidneys than females only in the left antimere. There was a positive linear correlation between the rostrum sacral length and ellipsoid volume of the left kidney only in males ( $\mathrm{r}=0.44$ and $\mathrm{P}=0.04)$.

In a study with nine male rabbits comparing fresh and fixed kidneys in formalin solution, Bolat et al. (2011) observed an increase inweight after fixation in both kidneys. They also found a decrease in the right kidney thickness after fixation. It was observed that the left kidneys were more affected by formalin fixation than right kidneys. No differences were observed in renal measures, similar partially to that observed in our study, because male cats have larger kidneys than females only in the left antimere.

By direct anatomical measurement, renal length in cats ranges from 3.8 to $4.4 \mathrm{~cm}$ (Walter et al., 1987). Previous ultrasonographical studies have reported that the normal size of the feline kidney varies between 3.0 and $4.3 \mathrm{~cm}$, and can even be up to $5.3 \mathrm{~cm}$ (Walter et al., 1987, Park et al., 2008). The result obtained in Ragdoll cats (Debruyn et al., 2013) of $3.83 \pm 0.45 \mathrm{~cm}$ (range 2.98-5.09) fits well within this interval and corresponds with the renal length found by Park et al. (2008) in healthy Korean domestic shorthair cats. The results of the authors above are similar to that observed in our study.

Mantis (2008) has suggested that Persian and Chinchillas tend to have smaller renal length than other breeds of cats, but further research is needed to evaluate if clinically relevant differences exist between cat breeds. In the study of Debruyn et al. (2013), male cats (4.29 \pm $0.40 \mathrm{~cm}$ ) tended to have larger kidneys than females $(3.64 \pm 0.32 \mathrm{~cm})$. This corresponds to the study of Shiroma et al. (1999) and partially to the results obtained in this study because de difference was observed only in left kidney. This difference in renal length between male and female cats may be partially explained by the difference in body length, as in our study male cats had a larger mean length $(48.25 \pm 0.56 \mathrm{~cm})$ than females $(45.19 \pm 0.70 \mathrm{~cm})$; nevertheless, the influence of the gender itself cannot be excluded.

In males the position of the right kidney ranged from L2 to L5. The left kidney ranged from L3 to L6. In females the position of the right kidney ranged from T13 to L6. The left kidney ranged from L2 to L6. These results are partially in agreement with Nickel et al. (1979) however the authors did not separate the results by gender.

In rabbits, every renal artery emits a caudal adrenal branch, sometimes up to two or three, along with a ureteric branch (Barone, 1996). However, another study (Bavaresco et al., 2013) found the phrenic-abdominal artery and occasionally one of the adrenal arteries as a side 
branch of the renal artery, which does not coincide with the literature referred to above. In the present investigation, the right and left renal arteries issued adrenal and ureteric branches.

The renal arteries in rabbits, golden hamsters and nutrias originate from the abdominal aorta laterally and caudally to the issuance of the cranial mesenteric artery and, in general, show asymmetrical layout, with the right vessel more cranial than the left vessel (Barone, 1996; Culau et al., 2008). In nutrias, a double renal artery was observed in the kidneys of $3.3 \%$ of animals, both right and left (Culau et al., 2008). In the year prior to this study, some researchers observed that in all animals, asymmetry was observed at the place of origin of the renal arteries, and the right cranial vessel was always more cranial than the left. However, the presence of double renal artery was not detected, but, in the absence in one case, to the left, because of the left kidney agenesis (Bavaresco et al., 2013). These results are similar to those obtained in the present investigation, but no renal agenesis was observed here. However, other authors have described the presence of double left renal artery (Almeida et al., 2013).

According to Ahasan et al. (2012) in rabbit, the renal arteries descend from the abdominal aorta. Although the origin of both renal arteries from the abdominal aorta varied, right renal artery descended cranial to the left renal arteries in 27 $(96.43 \%)$ cases. Similar relation was observed in 14 species (Human, Chimpanzee, Baboon, Pig tailed monkey, Stump faced monkey, Capuchin, greater Japanese shrew mole, lesser Japanese mole, rat, mongoose, mouse, rabbit, dog, hippopotamus). But in a single case both renal artery originated at same level. The same relation was reported in gibbon, marmoset, loris, and pig (Yokota et al., 2005).

In the same experiment, a difference was observed between the right and left renal artery lengths. In the present study, the male left renal artery was higher than the female left renal artery.

Therefore, research in cat anatomy should be encouraged for better comprehension of this animal.
Reis and Tepe (1956) dissected renal veins in 500 crossbred dogs, 287 males and 213 females, and observed the presence of double right renal vein in 5 animals (1\%), whereas the left renal vein was single in $100 \%$ of cases, different in part to the results obtained by Fagundes et al. (1990), in which the right and left renal vein were single in all dissections.

Duques et al. (2002) studied the renal vein in humans and found that in $91.1 \%$ (31) of the cases, the left renal vein was single and was double in only $8.9 \%$ (3). Similar result was obtained by Uzmansel et al. (2014), in a male cadaver.

During the dissection routine, Campos et al. (2014) found a numerical variation (double veins) in the renal veins of 3 cats, in the right and left kidneys of 1 female and in the right kidney of 1 female and 1 male. In the present study single, double, and triple renal veins were observed in the right kidney, and single and double veins in the left kidney.

Renal transplantation is a therapeutic alternative for cats in end-stage renal failure. Proper donor selection is an important component of any transplantation program. In feline renal transplantation, the requirements for the vascular anatomy of the harvested kidney are specific to ensure surgical success. Arterial anastomosis is most successful if there is a single renal artery with a length prior to branching of at least $0.5 \mathrm{~cm}$. If the vascular pedicle has more than one vein, the vein with the longest length and largest diameter is reserved for the anastomosis (Bouma et al., 2003).

\section{CONCLUSIONS}

The left kidney of males is larger than those of females. There was a positive linear correlation between the rostrum sacral length and ellipsoid volume of the left kidney only in males. The present study obtained results that are expected to contribute to the body knowledge in the field of comparative and applied anatomy, thus, providing subsidies for experimental, radiological and surgical practice in urology and nephrology. 


\section{ACKNOWLEDGEMENTS}

National Council of Technological and Scientific Development (CNPq), Rio de Janeiro Research Foundation (FAPERJ).

\section{REFERENCES}

AHASAN, A.S.; ISLAM, M.S.; KABRIA, A.S. et al. Major variation in branches of the abdominal aorta in New Zealand white rabbit (Oryctolagus cuniculus). Int. J. Sci., v.2, p.91-98, 2012.

ALMEIDA, B.B.; BARRETO, U.H.A.; COSTA, O.M.; ABIDU-FIGUEIREDO, M. Double renal artery in rabbits. Biosci. J., v.29, p.1295-1299, 2013.

BARONE, R. Angiology. In: (Ed.). Comparative anatomy of domestic mammals. Paris: Vigot, 1996. p.14-20.

BAVARESCO, A.Z.; CULAU, P.O.; CAMPOS, R. Visceral collateral branches of the abdominal aorta in New Zealand rabbits (Oryctolagus cuniculus). Acta Sci. Vet., v.41, p.1131-1136, 2013.

BOLAT, D.; BAHAR, S.; SELÇUK, M.L.; TIPIDARMAZ, S. Morphometric investigations of fresh and fixed rabbit kidney. Eurasian J. Vet. Sci., v.27, p.149-154, 2011.

BOUMA, J.L.; ARONSON, L.R.; KEITH, D.G.; SAUNDER, H.M. Use of computed tomography renal angiography for screening feline renal transplant donors. Vet. Radiol. Ultrasound, v.44, p.636-641, 2003.

CAMPOS, C.B.A.; ROCHA, P.S.; ABIDUFIGUEIREDO, M. Veia renal dupla em gatos: relato de casos. Rev. Acad. Ciênc. Agrár. Amb., v.12, p.127-131, 2014.

CULAU, P.O.; AZAMBUJA, R.C.; CAMPOS, $\mathrm{R}$. Visceral side branches of the abdominal aorta in Myocastor coypus (nutria). Acta. Sci. Vet., v.36, p.241-247, 2008.

DEBRUYN, K.; PAEPE, D.; DAMINET, S. et al. Renal dimensions at ultrasonography in healthy ragdoll cats with normal kidney morphology: correlation with age, gender and bodyweight. J. Feline Med. Surg., v.15, p.10461051, 2013.
DUQUES, P.; RODRIGUES, J.R.; SILVA NETO, F.B. et al. Estudo anatômico da veia renal esquerda de cadáveres humanos brasileiros. Medicina (Ribeirão. Preto), v.35, p.184-191, 2002.

ELKIN, M. Kidney size. In: (Ed.). Radiology of the urinary system. Boston: Little, Brown and Company, 1980. p.1014-1032.

FAGUNDES, G.M.; SOUZA, A.; BORELLI, V.; RIELLA, A.C.M. Contribuição ao estudo da drenagem sanguínea do rim de cães (Canis familiaris - Linnaeus, 1758). Biotemas, v.3, p.117-127, 1990.

FERNANDES, M.R.; LEMOS, C.S.; LOPES, G.S. et al. Normal renal dimensions in a specific population. Int. Braz. J. Urol., v.28, p.510-515, 2002.

GUPTA, S.; DEVI, N.D.; SINAM, S.S. et al. Ultrasonographic renal dimensions in normal adult population of north-east India. Int. J. Med. Health Sci., v.2, p.433-437, 2013.

MANTIS, P. Ultrasonography of the urinary and genital system of the dog and cat. Iran. J. Vet. Surg., Suppl.1, p.63-71, 2008.

MÖELL, H. Size of normal kidneys. Acta Radiol., v.46, p.640-645, 1956.

NICKEL, R.; SCHUMMER, A.; SEIFERLE, E. Urogenital system. In: (Eds.). The anatomy of the domestic animals. Berlin: Verlag Paul Parey, 1979. p.282-304.

OYELA-CARRASCO, J.; RODRÍGUEZCASTELLANOS, F.; KIMURA, E. et al. Renal lenght by ultrasound in Mexican adults. Nefrologia, v.29, p.30-34, 2009.

PARK, I.; LEE, H.; KIM, J. et al. Ultrasonographic evaluation of renal dimension and resistive index in clinically healthy Korean domestic short-hair cats. J. Vet. Sci., v.9, p.415419, 2008.

PETERS, M.; JANCKE, L.; STAIGER, J.F. et al. Unsolved problems of comparing brain sizes in homo sapiens. Brain Cogn., v.38, p.254-285, 1998.

REIS, R.H.; TEPE, P. Variations in the pattern of renal vessels and their relation to the type posterior vena cava in the dog (Canis familiaris). Am. J. Anat., v.99, p.1-15, 1956. 
SAMPAIO, F.J. Theoretical kidney volume versus real kidney volume: comparative evaluation in fetuses. Surg. Radiol. Anat., v.17, p.71-75, 1995.

SAMPAIO, F.J.; MANDARIN-DE-LACERDA, C.A. Morphometry of the kidney: applied study in urology and imaging. J. Urol., v.95, p.77-80, 1989.

SAMPAIO, F.J.; PEREIRA-SAMPAIO, M.A.; FAVORITO, L.A. The pig kidney as an endourologic model: anatomic contribution. $J$. Endourol., v.12, p.45-50, 1998.

SCHMIEDT, C.W.; NELSON, S.A.; BRAINARD, B.M. et al. Bilateral renal ischemia as a model of acute kidney injury in cats. Res. Vet. Sci., v.93, p.950-959, 2012.
SHIROMA, J.T.; GABRIEL, J.K.; CARTER, R.L. et al. Effect of reproductive status on feline renal size. Vet. Radiol. Ultrasound, v.40, p.242245, 1999.

UZMANSEL, D.; OZTURK, N.C.; KARA, A.; OZTURK, A. A rare combination of vascular variations of both kidneys. Surg. Radiol. Anat., v.36, p.195-198, 2014.

WALTER, P.A.; FEENEY, D.A.; JOHNSTON, G.R.; FLETCHER, T.F. Feline renal ultrasonography: quantitative analyses of imaged anatomy. Am. J. Vet. Res., v.48, p.596-599, 1987.

YOKOTA, E.; KAWASHIMA, T.; OHKUBO, F. Comparative anatomical study of the kidney position in amniotes using the origin of the renal artery as a landmark. Okajimas Folia Anat. Jpn., v.81, p.135-142, 2005. 